\title{
HUBUNGAN BERAT BADAN IBU HAMIL PADA TRIMESTER DUA DAN \\ TIGA DENGAN STATUS KESEHATAN JARINGAN PERIODONTAL DI PUSKESMAS ANDALAS PADANG
}

\author{
Rydwan Efendi', Yustini Alioes ${ }^{2}$, Eni Rahmi ${ }^{1}$ \\ ${ }^{1}$ Fakultas Kedokteran Gigi Universitas Andalas \\ ${ }^{2}$ Fakultas Kedokteran Universitas Andalas
}

\begin{abstract}
The increasing production of hormone estrogen and progesteron during pregnance known as a risk factors of periodontal disease during pregnance. The other risk factor of periodontal disease during pregnance is obesity, because adipose tissue in obesity person produce pro inflamatory cytokines that influence periodontal status. Both of this risk factors could happen in pregnance woman. During pregnancy, production of hormones estrogen, progesteron and the weight is gained. The aim of this study was to evaluate the relationship between weight during pregnance with periodontal status. This research was an observational analytic with crossectional comparative, with 52 sampels. CPI indeks was used to evaluate the periodontal status meanwhile weight during pregnance was measured by GWS IOM. The resulting data were analyzed by chi-square test. There were significantly differences between pregnance weight at trimester $2^{\text {nd }}$ and $3^{\text {rd }}$ with increasing of the Community Periodontal Indeks.
\end{abstract}

Keywords: pregnancy woman, pregnancy weight, hormon, and periodontal disease

Affiliasi penulis: ${ }^{1}$ Fakultas Kedokteran Gigi Universitas Andalas Korespondensi: eni rahmi, email: eni.rahmi@dent.unand.ac.id

\section{PENDAHULUAN}

Menurut Profil Kesehatan Indonesia jumlah ibu hamil pada tahun 2013 meningkat dari tahun 2011 yaitu: dari 5.060.637 jiwa menjadi 5.136.041 jiwa. Upaya untuk meningkatkan kesejahteraan ibu hamil terus ditingkatkan oleh tenaga medis, hal ini dapat dilihat dari meningkatnya Ante Natal Care (ANC) sebanyak 95,5\%. Peningkatan pelayanan kesehatan ini dirasa masih kurang karena masih terdapat beberapa masalah kesehatan pada ibu hamil, salah satunya masalah kesehatan rongga mulut yaitu gingivitis pada saat kehamilan. Saat ini prevalensi gingivitis pada ibu hamil sekitar 30$100 \% .^{1,2}$

Selama kehamilan banyak terjadi perubahan pada ibu hamil. Perubahan sistemik ataupun lokal terjadi untuk mengimbangi perkembangan janin yang ada dalam uterus. Perubahan pertama adalah perubahan fisologis serta anatomis pada jantung ibu hamil akibat meningkatnya kebutuhan suplai darah pada janin. Perubahan ini diikuti dengan perubahan pada paru-paru karena meningkatnya jumlah kebutuhan oksigen. Peningkatan aktivitas pada ginjal juga terjadi untuk menyeimbangkan cairan serta asambasa yang terjadi karena peningkatan 
cairan intersisial dalam tubuh. Umumnya perubahan yang terjadi pada ibu hamil distimulasi oleh adanya hormon, baik secara langsung atau tidak langsung. ${ }^{3,4}$

Pada saat kehamilan terjadi peningkatan hormon estrogen dan progesteron yang sangat signifikan. Hormon progesteron pada saat kehamilan awalnya dihasilkan oleh korpus luteum yang berfungsi untuk mempersiapkan uterus agar implantasi dapat terjadi dengan baik selama trimester pertama. Fungsi sekresi oleh korpus luteum nantinya akan digantikan oleh plasenta. Kenaikan estrogen pada ibu hamil juga memiliki peranan penting selama kehamilan, dalam merangsang terbentuknya saluran air susu pada payudara. Peningkatan kedua hormon ini selama kehamilan tidak hanya berdampak pada organ kehamilan saja, tapi juga bisa berpengaruh terhadap fungsi organ lain bahkan sampai ke rongga mulut. ${ }^{4,5}$

Banyak ahli yang telah melakukan penelitian tentang pengaruh hormonal pada ibu hamil terhadap kondisi rongga mulut. Beberapa peneliti melaporkan bahwa konsentrasi hormon estrogen dan progesteron yang tinggi pada ibu hamil dapat merubah keadaan komposisi mikroflora pada subgingiva ibu hamil. Mikroorganisme seperti P.intermedia, P.melanogenica,
C.reaktus, T.forsyntesis dilaporkan mengalami peningkatan selama kehamilan. Peningkatan mikroorganisme ini juga diikuti dengan terjadinya penyakit periodontal seperti gingivitis. $^{4}$

Janin pada uterus akan mengalami fase embriogenik dan organogenesis. Pada keadaan ini tubuh ibu hamil juga akan mengalami pertambahan berat badan mengikuti perkembangan janin. Pertambahan berat badan pada ibu hamil sangat individualistik dan dipengaruhi oleh beberapa faktor, yaitu genetik dan lingkungan. Menurut standar Indeks Massa Tubuh (IMT) yang telah ditetapkan oleh WHO, jika indeks massa tubuh ibu sebelum hamil adalah ideal $(18,5-24,9)$ maka pertambahan berat badan ibu yang ideal menurut Institute of Medicine (IOM) Gestational Weight Gain (GWG) adalah sekitar 11-16 kg. Jika terjadi peningkatan lebih 11-16 kg akan meningkatkan risiko penyakit lain pada ibu hamil seperti Diabetes Melitus (DM) kehamilan, dan preeklamsi kehamilan. ${ }^{6-9}$

Pertambahan berat badan pada ibu hamil dicurigai memiliki hubungan dengan penyakit periodontal. Berat badan ibu hamil yang berlebih diduga dapat memperparah keadaan penyakit periodontal. Pendapat ini diambil berdasarkan penelitian para ahli 
terdahulu yang mengatakan bahwa selama kehamilan terjadi peningkatan penyakit gingiva akibat hormon kehamilan, dilain pihak jaringan adiposa pada orang yang mengalami obesitas akan mempoduksi sitokin sehingga meningkatkan terjadinya penyakit periodontal. Namun saat ini belum ada penelitian yang menunjukkan bahwa ibu hamil yang mengalami peningkatan berat badan lebih dari normal memiliki penyakit periodontal lebih parah. ${ }^{9,10}$

Berdasarkan data Dinas Kesehatan Kota Padang jumlah ibu hamil pada wilayah kerja Puskesmas Andalah 1769 orang. Laporan tahunan Puskesmas Andalas tahun 2013 juga menunjukkan bahwa penyakit periodontal dan gingivitis merupakan penyakit terbanyak ketiga dengan jumlah penderita sebanyak 2588. Penderita penyakit gingivitis juga banyak terjadi pada perempuan daripada laki-laki. Penelitian yang dilakukan oleh Gustria Rahayu di Puskesmas Andalas tahun 2012 menunjukkan bahwa 70 responden ibu hamil yang diperiksa semuanya mengalami gingivitis. ${ }^{11-13}$ Berdasarkan survey awal yang telah peneliti lakukan di Puskesmas Andalas, pertambahan berat badan pada ibu hamil masih kurang diperhatikan dengan baik, hal ini terlihat dengan tidak adanya pengukuran IMT sebelum kehamilan guna mempertimbangkan berat badan yang ideal selama kehamilan. Oleh karena itu penulis tertarik melakukan penelitian tentang hubungan berat badan ibu hamil pada trimester dua dan tiga dengan status kesehatan jaringan periodontal di Puskesmas Andalas.

\section{METODE}

Jenis penelitian yang dilakukan adalah crossectional comparative. Besar sampel dalam penelitian ini 52 orang, dengan rumus 2 kelompok beda proporsi. Tujuan penelitian ini untuk mengetahui hubungan antara berat badan ibu hamil dengan status kesehatan jaringan periodontal.

Untuk mengukur berat badan badan ibu hamil adalah dengan cara membandingkan pertambahan berat badan ideal menurut IOM GWG dengan pertambahan berat badan ibu hamil. Status kesehatan periodontal ibu hamil di ukur dengan menggunakan indeks CPI.

\section{HASIL DAN PEMBAHASAN}

Setelah dilakukan pemeriksaan maka didapatkan data status kesehatan jaringan periodontal, status berat badan ibu hamil, dan hubungan antara berat badan ibu di Puskesmas Andalas sebagai berikut:

Tabel 1. Status Kesehatan Periodontal IbuHamil di Puskesmas Andalas

\begin{tabular}{ccc}
\hline $\begin{array}{c}\text { Status Kesehatan } \\
\text { Periodontal }\end{array}$ & $\mathrm{n}$ & $\%$ \\
\hline Sehat & 16 & 30,8 \\
\hline
\end{tabular}




\begin{tabular}{ccc}
\hline Sedang & 36 & 69,2 \\
Total & 52 & 100,0 \\
\hline
\end{tabular}

Dari 36 orang ibu hamil yang mengalami status kesehatan periodontal sedang 16 diantaranya mengalami pertambahan berat badan berlebih $(44,45 \%)$.

Tabel 2. Status berat badan ibu hamil

\begin{tabular}{ccc}
\hline $\begin{array}{c}\text { Status berat } \\
\text { badan }\end{array}$ & $\mathrm{n}$ & $\%$ \\
\hline Normal & 34 & 65,4 \\
Berlebih & 18 & 34,6 \\
Total & 52 & 100,0 \\
\hline
\end{tabular}

Delapan belas orang ibu hamil yang mengalami berat badan berlebih memiliki rata-rata pertambahan berat badan $3,39 \mathrm{~kg}$.

Tabel 3. Distribusi Status Kesehatan Jaringan Periodontal dihubungkan dengan Status Berat Badan dan Usia Kehamilan

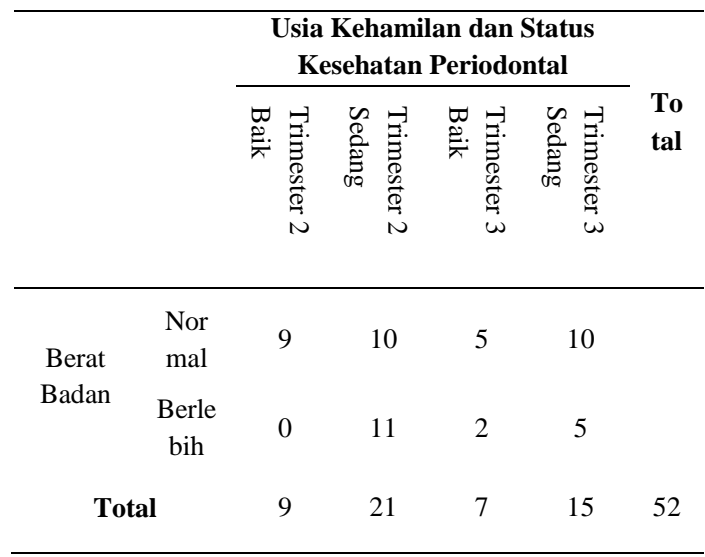

Tabel 4. Hasil analisis hubungan antara berat badan ibu hamil dengan status kesehatan periodontal

\begin{tabular}{cccccc}
\hline & & \multicolumn{2}{c}{ Status Perio } & \multirow{2}{*}{ total } & $\boldsymbol{p}$ \\
\cline { 3 - 5 } & & Baik & Sedang & & \\
\hline Berat & Normal & 14 & 20 & 24 & \\
badan & Berlebih & 2 & 16 & 18 & 0,025 \\
\multicolumn{2}{c}{ Total } & 16 & 26 & 52 & \\
\end{tabular}

Pada penelitian ini dari 52 responden ibu hamil yang diperiksa ditemukan 16 orang memiliki status periodontal baik $(30,8 \%), 36$ orang memiliki status kesehatan jaringan periodontal sedang $(69,2 \%)$, sedangkan ibu hamil dengan status kesehatan periodontal buruk tidak ditemukan. Usia kehamilan ibu saat penelitian ini dilakukan adalah 14 minggu sampai 40 minggu. Masalah gingivitis dan periodontitis pada ibu hamil atau pada orang yang tidak hamil disebabkan oleh plak, namun pada ibu hamil terdapat beberapa faktor risiko yang dapat memperparah penyakit periodontal selama kehamilan. ${ }^{17}$ Faktor risiko tersebut antara lain: mual-mual selama kehamilan (disebabkan asam yang dikeluarkan waktu mual dapat menyebabkan ganguan mikroflora yang dapat menyebabkan gingivitis), pengaruh hormonal, adanya perkembangan bakteri spesifik (Provotela intermedia), dan adanya penurunan sistem imun. ${ }^{4,13}$

Berdasarkan hasil penelitian ini, ibu hamil yang mengalami penyakit periodontal sebanyak 69,2\%. Hasil penelitian di Puskesmas Andalas ini hampir sama dengan penelitian Wandera et al pada ibu hamil di Uganda tahun 2009, yang menyatakan ibu hamil yang mengalami penyakit periodontal sebanyak 67,3\%. ${ }^{4}$ Menurut Markou et al (2009), hormon kehamilan estrogen dan progesteron merupakan hormon yang berpengaruh terhadap kesehatan 
jaringan periodontal. Hormon estrogen dan progesteron memiliki beberapa mekanisme dalam mempengaruhi kesehatan jaringan periodontal. ${ }^{4}$

Hormon didalam tubuh memiliki reseptor. Hormon estrogen memiliki dua jenis reseptor yaitu: ER-alpha dan ERbeta. Reseptor ER-beta tersebar luas didalam rongga mulut dan terlibat dalam beberapa proses fisiologis yang penting, antara lain: diferensiasi sel, pengorganisasian matrik ektraseluler dan komunikasi stromal-epithelial. Terlibatnya estrogen dalam beberapa proses fisiologis ini akan mempengaruhi kolagen gingiva. Awalnya estrogen akan menurunkan produksi dan keratinisasi dari kolagen serta menghambat pergantian gingiva sehingga mengurangi kemampuan gingiva untuk memperbaiki diri. Terjadinya proses ini pada gingiva mengakibatkan peningkatan permeabilitas dari epitelial barrier sehingga respon terhadap plak juga ikut mengalami peningkatan. ${ }^{4}$

Aktivitas hormon progesteron terlihat pada fibroblast gingiva. Fibroblast dan makrofag gingiva menghasilkan Plasminogen Activator Inhibitor type-2 (PAI-2). Progesteron akan mempengaruhi PAI-2 sehingga menyebabkan terganggunya keseimbangan dari sistem fibrinolitik. Selama kehamilan juga dilaporkan produksi dari PAI-2 sulit untuk dihentikan karena produksi inhibitornya diganggu oleh hormon progesteron. Progesteron juga memiliki efek terhadap peningkatan eksudat gingiva, permeabilitas pembuluh darah, dan proliferasi pembuluh darah. ${ }^{4}$ Menurut Jensen et al (1981) serta Korman dan Loesche (1982), tingginya kadar hormon estrogen dan progesteron selama kehamilan juga akan diikuti peningkatan beberapa bakteri spesifik. Peningkatan populasi Provotela intermedia dalam rongga mulut juga dilaporkan terjadi selama kehamilan. Provotela intermedia merupakan bakteri berpigmen hitam, gram-negatif anaerob dengan jenis batang. Bakteri ini untuk proses perkembangbiakannya membutuhkan vitamin $\mathrm{K}$ dan napthoquinone. Fungsi kedua zat ini dapat digantikan oleh estrogen dan progesteron yang kadarnya meningkat dalam saliva selama kehamilan. Peningkatan Provetela intermedia akan meningkatkan terjadinya gingivitis pada ibu hamil dengan ciri klinis terjadi perdarahan sewaktu dilakukan probbing tanpa adanya peningkatan jumlah plak. ${ }^{4}$

Menurut Gustria R (2012), dari 70 responden ibu hamil yang diperiksa di Puskesmas Andalas sebanyak 8 ibu hamil mengalami gingivitis berat. Hasil yang didapatkan Gustria $\mathrm{R}$ ini berbeda dengan penelitian ini, karena tidak ditemukannya ibu hamil yang 
mengalami status periodontal buruk. ${ }^{13}$ Tidak ditemukannya ibu hamil yang memiliki status periodontal buruk mungkin disebabkan oleh sampel yang dipilih dalam penelitian ini status IMT sebelum kehamilan ibu normal, jadi dapat di asumsikan peranan jaringan adiposa terhadap keparahan status kesehatan jaringan periodontal hanya terjadi pada masa kehamilan dimana ibu hamil memiliki berat badan yang berlebih selama kehamilan. Gustavo G dalam penelitiannya menjelaskan bahwa individu yang memiliki status periodotal paling buruk adalah individu yang kondisi berat badannya pada awal dewasa muda obestitas atau overweight mengalami peningkatan berat badan pada saat dewasa. Individu yang berat badannya obesitas atau overweight pada masa dewasa muda dan mengalami penuruan berat badan pada masa dewasa memiliki kondisi jaringan periodontal kedua terburuk, sedangkan individu yang berat badannya normal pada awal dewasa muda jika mengalami pertambahan berat badan menjadi obesitas atau overweight memiliki kondisi jarigan periodontal yang lebih baik dari kondisi yang diatas. Menurut Gustavo $G$ hal ini terjadi dikarenakan seseorang yang terpapar sitokin pada dewasa muda akan mengalami kerusakan yang lebih parah dibandingkan dengan seseorang yang terpapar sitokin pada saat dewasa. ${ }^{18}$

Berat badan ibu hamil diukur berdasarkan pertambahan berat badan ideal pada ibu selama kehamilan trimester dua dan tiga. Pertambahan berat badan selama kehamilan merupakan hal yang penting karena mempengaruhi kesehatan janin dan ibu. Pertambahan berat badan selama kehamilan ini merupakan proses fisiologis yang terjadi selama kehamilan yang menandakan adanya perkembangan janin. IOM mengeluarkan panduan pertambahan berat badan untuk ibu hamil (2009) yang menjelaskan bahwa pertambahan berat badan ideal selama kehamilan dapat diukur berdasarkan IMT ibu sebelum kehamilan. ${ }^{9}$

Menurut Rebecca et al (2010), salah satu hal yang mempengaruhi pertambahan berat badan pada ibu hamil adalah gangguan pola makan. Gangguan pola makan adalah kelainan psikologis pada sesesorang ditandai dengan adanya kelainan kebiasaan pada pola makan yaitu pola makan berlebih atau kurang. ${ }^{16}$ Pada penelitian ini ditemukan dari 52 orang responden terdapat 18 orang $(34,6 \%)$ diantaranya memiliki berat badan berlebih. Hal ini sesuai dengan penelitian yang dilakukan oleh Nan Li yang melaporkan dari 33.973 responden 
ibu hamil 19.406 diantaranya memiliki berat badan berlebih. ${ }^{8}$

Penelitian J. Karles (2007) dan Chitsazi (2008) menyatakan bahwa kondisi seseorang yang mengalami obesitas dan overweight mempengaruhi kesehatan jaringan periodontal dikarenakan jaringan lemak tubuh menghasilkan beberapa jenis sitokin yang memperparah kondisi kesehatan jaringan periodontal. Menurut Nan Li (2013), dan Lindneimer (2008), berat badan yang berlebih selama kehamilan menyebabkan beberapa masalah kesehatan selama kehamilan, antara lain diabetes melitus kehamilan, hipertensi kehamilan, proses lahir cesar, dan beberapa masalah kesehatan lainnya. Saat ini belum ada penelitian yang mengatakan berat badan yang berlebih selama kehamilan mempengaruhi kesehatan periodontal. Pada ibu hamil yang memiliki berat badan yang berlebih saat ini belum ada penelitian yang menyatakan bahwa berat badan ini adalah pertambahan jaringan adiposa, karena pada ibu hamil bisa saja yang memiliki berat badan berlebih ini diakibatkan adanya pertambahan berat janin, cairan amnion dan yang lainnya. ${ }^{4,8,16,20,21}$

Jennifer (2009) menyatakan bahwa setelah kehamilan akan terjadi retensi berat badan pada ibu hamil jika mengalami pertambahan berat badan yang berlebih selama kehamilan. Berdasarkan pernyataan ini dapat disimpulkan bahwa ibu hamil yang mengalami pertambahan berat badan berlebih memiliki kemungkinan untuk mengalami perubahan status IMT setelah kehamilan, misalnya status IMT sebelum kehamilan normal mengalami pertambahan berat badan berlebih saat hamil maka setelah kehamilan status IMT menjadi overwight. ${ }^{17}$

Pada ibu hamil yang mengalami pertambahan berat badan berlebih selama kehamilan juga memiliki kebiasaan atau asupan makan yang lebih banyak dibandingkan dengan ibu hamil dengan pertambahan berat badan normal. Asupan makan yang banyak ini juga harus diimbangi dengan peningkatan dalam menjaga kebersihan rongga mulut. Menurut Diana dewi (2009), selama kehamilan ibu hamil cenderung malas untuk beraktivitas termasuk dalam menjaga kebersihan rongga mulut. Kebersihan mulut yang kurang diperhatikan selama kehamilan ini juga akan mempengaruhi kesehatan jaringan periodontal.

\section{SIMPULAN}

Ibu hamil pada Puskesmas Andalas yang memiliki berat badan normal adalah sebanyak 34 orang $(65,4 \%)$, sedangkan 18 orang lainnya memiliki berat badan berlebih $(34,6 \%)$. 
Status kesehatan periodontal ibu hamil di Puskesmas Andalas adalah 16 orang ibu hamil memiliki status kesehatan jaringan periodontal sehat (30,8\%), 36 orang dengan status sedang $(65,4 \%)$, sedangkan status periodontal buruk tidak ditemukan. Sehingga dapat disimpulkan bahwa hasil analisis hubungan antara berat badan ibu hamil dengan status kesehatan jaringan periodontal di Puskesmas Andalas menunjukkan adanya hubungan yang bermakna secara statistik.

\section{KEPUSTAKAAN}

1. Otomo, I. Corgel. In Carranza. Clinical Periodontology 9th Edition. USA : W.B. Saunders Co. 2002. p: 513-525

2. Depkes RI. Riset Kesehatan Dasar 2013. Jakarta : BPPK. 2014

3. Beckmann R.B, C. Obstetrics and Gynecology 6th Edition, Cina : ACOG, 2010. p: 45-50

4. Lafaurie, I. G. Gingival Tissue and Pregnancy, Gingival Disease Their Aetiology, Prevention and Treatment. Colombia : InTech Open. 2011. p: 101-105

5. Adriaansz, G. Asuhan Neonatal, Indonesia, $2008: 1$

6. WHO. Obesity and Overwight : WHO. 2003

7. Dept. of Health. Adult Body Mass Index (BMI) Chart. Vermont. 2007
8. Li Nan, et al. Maternal Prepregnancy Body Mass Indeks and Gestational Weight Gain on Pregnancy Outcome. China : Plosone.Org. 2013 : 1-2

9. Rasmussen M, K. Weight Gain During Pregnancy Reexamination the Guidelines. North Carolina : Inst Med. 2009.

10. De Casttilhous, E. D et al. Association between Obesity and Periodontal Disease in Young Adult. A Population- Based Birth Cohort. Brazil : J. Clinc Perio. 2012 p: $717-718$

11. Puskesmas Andalas. Laporan Akhir Tahun Puskesmas Andalas 2013. Padang : Puskesmas Andalas. 2014

12. Rahayu. G. Pengaruh Kebersihan Gigi dan Mulut dengan Status Gingivitis pada Ibu Hamil di Wilayah Kerja Puskesmas Andalas Kecamatan Padang Timur Kota Padang Tahun 2012. Padang : J. Andalas 2012 p: 217-224

13. Lindneimer $\mathrm{D}, \quad \mathrm{M}$ et al. Hypertension in pregnancy. United State : J Am Society Hypertension. 2008. p: 484-485

14. Chitsazi T. Mohammad, et al. Association of Periodontal Disease with Elevation of Serum C-reaktive Protein and Body Mass Index. Iran : T Univ Med Sci. 2008. p: 9-11 
15. J. Kareles, A, et al. Obesity and its Role in Oral Health. United State :Int J Allied Health Sci Pra. 2007. p: $1-4$

16. Rebecca, A, et al. Attitudes Toward Weight Gain During Pregnancy: Result from the Norwegian Mother and Child Cohot Study (Moba). Int. J. Eat. Discord. 2010. p.394-401

17. Jenifer, NG, et al. Maternal Overweight, Obesity and Excess Gestational Weight Gain. BC Perinatal Health Program. 2009.

18. Nascimento, GG, et al. Relationship Between Periodontal Disease and Obesity: The Role of Life-Course Event. Brazilian Dental J.2014.p.87-89 